\title{
II. PRACTICAL AND DEVOTIONAL.
}

\section{FOR THE WORK OF THE MINISTRY.}

By T. Harwood Pattison, D.D., Elaborated by his son, Harold Pattison. American Baptist Publication Society, Philadelphia. 1907. Pages 558. Price, $\$ 1.50$ net. Postage, 15 cents.

The lamentable death of Dr. Pattison left the material for this volume incomplete in the shape of his lectures to his classes in Pastoral Theology at Rochester Seminary; but his son, the Rev. Herold Pattison of Hartford, has worked out from his father's notes and sketches the material of the book. Besides this he has added a strong chapter at the close upon the present day value of the ministry. The book itself takes its place along with the previous works of the distinguished author; his reputation will suffer nothing by the bringing out of this posthumous volume. The genial personality, which even readers who did not know the author have already recognized under Dr. Pattison's pleasing style, is here again in evidence. The devout tone and sound sense which have marked his earlier volumes are not wanting here. The clear winsome style characteristic of the writer shows itself also in this. One is never at a loss for Dr. Pattison's meaning. Inasmuch as the book consists chiefly of lectures to theological under-graduates, it contains much that more experienced pastors may be supposed to know. But this inevitable commonplace is put forth in such agreeable style as to be interesting and suggestive. Indeed, one is scarcely conscious of any abatement of interest; because even the most familiar topics are freshly and pleasantly treated. Any pastor will find stimulus and help in reading the book. It abounds in practical suggestions on all the most important elements of a pastor's life. The balanced judgment, good humor and vigorous manliness of the treatment must commend themselves to all readers. The author begins by discussing the importance of the pastor's health and next discourses on ministerial manli- 
ness. Not to mention all topics, he discusses such matters as the call, ordination, work and devotion of the preacher. Then his relations to the church, in its various departments of labor, are wisely discussed. Revivals receive judicious consideration, pastoral visiting and the social contact are also helpfully considered. Altogether it is a wholesome, judicious and spirited book.

$$
\text { E. C. Dargan. }
$$

\section{THAT THEY ALL MAY BE ONE.}

A reunion sermon by Alexander Whyte, D.D., of Edinburgh. A. C. Armstrong \& Sons, New York. Pages, 32.

This sermon was preached in St. George's United Free church, Edinburgh, on Whitsunday, 1906. It was occasioned by a letter on the unity of churches, signed by the archbishops of Canterbury and York, and the Presidents of various Non-Conformist church bodies in Great Britain. It is a strong and vigorous plea, not for organic, but a larger spiritual unity among churches of all sects. The plea is based primarily on self-examina tion. The preacher rightly holds that the heart must be right first. The keynote is, "Look not every man on his own things, but every man also on the things of others." The principle of the sermon is highly commendable. One must take issue, however, with the distinguished preacher when he says (page 30): "The first step toward a real unity of Christendom will be at hand when we come to see and realize that the Greek church was the original mother of us all." If he had said the New Testament church he would have been nearer the truth.

E. C. Dargan.

\section{THE MINISTRY OF RECONCILIATION.}

Sermon by Charles F. Aked, D.D., Pastor of the Fifth Avenue Baptist Church, New York. F. H. Revell Company, New York. Pages 27. 10 cents.

Dr. Aked has been very cordially received on coming from England to assume charge of his very important. 